\title{
ENHANCING STUDENTS' LOCAL KNOWLEDGE THROUGH THEMED GARDEN PROJECT
}

\author{
Norizan Esa \\ School of Educational Studies, \\ Universiti Sains Malaysia, Malaysia \\ and \\ Rabiatul Adawiah Megat Jiwa \\ SEAMEO-RECSAM, Pulau Pinang, Malaysia
}

\section{ABSTRACT}

Traditional or local knowledge is a major issue to be focused on, particularly since the implementation of the Strategic Plan for Biodiversity 2011-2020 and the Aichi Targets "Living in Harmony with Nature". According to the strategic goals, by 2020, conservation of biodiversity and its sustainable use incorporate what local and indigenous communities have within their traditional knowledge, innovation and practice and their customary use of biological resources are respected at all relevant levels. The older generation among the local people usually use medicinal herbs for various ailments, health care and other cultural purposes. However, encroaching industrialization and the changes in today's life styles are responsible for the decreasing practice in the local use of herbs especially for healing purposes. It is, therefore, felt worthwhile to encourage young generations such as school children to gain knowledge about these local herbs and record the native uses of these herbs before the information is lost. One biodiversity education program was conducted to facilitate secondary school students to set up a themed garden and find out the local knowledge of the plants they grew in their garden from their family members or communities. The findings revealed that students' local knowledge on healing improved after they joined the program. Therefore, it is proposed that the themed garden project can enhance students' local knowledge.

Key Words: Local knowledge, Garden project, Students

\section{INTRODUCTION}

Malaysia is blessed with a huge variety of plant species, being one of the world's 12 megabiodiversity., Her rainforest is reported to consist of about 1500 species of higher plants, 1200 of which are reportedly useful for its pharmaceutical value. Some of these are already in use as herbal medicine (Rasadah and $\mathrm{Li}, 2009$ ). In herbal medicine, all parts of the plant may be used be it the stem, leaf, flower, seed etc to facilitate general well being or to treat certain ailments.

Practitioners of traditional healing acquire their knowledge and expertise through informal means. Much of the learning is through observation and practice, facilitated by oral means and passed down through generations. However, the sustainability of this knowledge is threatened when the practitioners do not have anyone to inherit their knowledge, as when they have no children or their children and other people from the younger generation have no interest to train and practice in this field Supiah Mustaffa, Ros'aleza Zarina Ishak, Lee, C. K., Lim, S. N, Sintoh, M. and Nor Ezam Selan (2012).

Local knowledge is that acquired through the ages and within a particular locality. This knowledge is embedded in the customs and culture of the place. Thus the rest of the world may have a 
glimpse and may even begin to understand the different ways specific comunities interact with their environment, and the resources available within their environment. The United Nations Conference on Environment and Development held in June 1992 in Rio de Janeiro has suceeded in heightening awareness on the global crisis of biodiversity and its conservation. Conservation of biodiversity is also evident in local knowledge,also known as indigenous knowledge. Local knowledge, particularly in the Malaysian context, has long been ignored and this knowledge is found to be limited among students nowadays. It is, therefore, felt worthwhile to encourage the young generation such as school children to gain this local knowledge, and record the native uses of these herbs before the information is lost (Warren, 1992).

Outdoor experiences and education about the environment seems to be able to develop student's value towards local knowledge on biodiversity. Fostering in students a value for the environment and biodiversity by incorporating outdoor experiences in science education is the most important step in ensuring a balance between experiencing, learning and caring. Unfortunately, for many students, learning science does not involve these types of opportunities. Besides that, students also fail to observe ecological relationships in their day to day activities. Other researchers assert that the real problem comes when ecological knowledge is not seen as important for the student (Bowers, 2003). Understanding of patterns in nature is de-emphasized or ignored for a human economy based on the exchange of money for material and conveniences of life. To engage people in environmental issues such as the biodiversity and local knowledge crisis, connection with nature is one of the solutions.

\section{LITERATURE REVIEW}

Traditional healing uses plants as its main resource and this has been the practice for several thousand years (Louv, 2006, Revathi \& Parimelazhagan, 2010). Since time memorial, mankind has used herbal remedies in health care. The knowledge and associated systems that has evolved over several millennia within communities have remained as the foundation of traditional knowledge in healing (Mukherjee and Wahil, 2006). Traditionally, this treasure of knowledge has been passed on verbally from generation to generation without any written document (Perumal Samy \& Ignacimuthu, 2000) and is still retained by various local people around the world.

Malaysia has rich traditional knowledge associated with biodiversity. This indigenous knowledge has been acquired over ages and treasured by the local communities and the tribals, particularly those living in and around the forests and agro-ecosystems. Very little of this knowledge has been documented. In Malaysia, we have noticed that the knowledge of herbal medicine is continually lost over the centuries due to lack of a proper system for documenting, conserving, sharing and discovering this knowledge (Sahri, Nordin, \& Harun, 2012).

The Strategic Plan for Biodiversity 2011 - 2020 and the Aichi Targets of Living in Harmony with Nature are blueprints for ensuring that conservation of biodiversity and its sustainable use incorporate what local and indigenous communities have within their traditional knowledge, innovation and practice. Therefore, educational institutions are expected to play a critical role to educate their students for a better understanding in biodiversity (CBD, 2010).

There are various factors and impact of personal environmental knowledge, attitudes, uses, concern and these factors are somehow related to each others. Previous studies examined students' environmental knowledge, attitudes and activity levels and found significant variations among students, based on their gender and educational background (Tikka, Kuitunen and Tynys, 2000). The students who demonstrate highly positive attitude towards the environment and high knowledge about the 
environment are the Biology students. It is therefore encouraging that the themed garden project can enhance local knowledge towards biodiversity among students.

\section{METHODOLOGY}

This study is a qualitative method to investigate students' local knowledge on plants through a themed garden project. The qualitative method is used in this study to obtain information that cannot be obtained using quantitative methods. Qualitative methods are especially useful for gathering and analyzing exploratory data. It is more efficient to study human behavior and behavior changes because complex behavior is not well captured by quantitative techniques.

\section{SAMPLE}

This study focuses on secondary school students. The sample involved in this study consists of 200 students from the science stream. Interview sessions were conducted to identify their local knowledge about plants in depth.

\section{INSTRUMENT}

The instrument used is structured interview questions. In the garden project, students sourced information from their parents and other family members. The information is about local knowledge or traditional home appliances using plants. An interview was carried out to allow for deeper probing from where they obtain the knowledge and whether it is effectively used.

\section{THEMED GARDEN PROJECT}

Through this themed garden project, students were assigned into ten different themed gardens that focus on different types of plants. The themed gardens are, Malay herbs garden, Indian herbs garden, Chinese herbs garden, Vitamin garden, Jam garden, Coloured garden, Heritage garden, Nasi ulam garden, Edible garden and Recycle garden. Students were given two months to develop their themed garden and another month to collect the information about their plants in the themed garden. Information about the plants must be acquired from the older people or traditional practitioner. At the end of the project, students need to present and share their findings about their themed garden. In depth interview were used to get details about the information given.

\section{RESULTS}

For this paper, the results will focus on the herb gardens for healing purposes only. Data obtained through interviews showed an increase in local knowledge on healing among students. Respondents also mentioned that when they obtained local knowledge of particular plants from the older family members, they try to prove that the information give is correct. The result shows positive attitude towards the information given. Table 1 gives the information about local knowledge on healing during the analysis of the interviews.

Table 1 Local knowledge on healing

\begin{tabular}{|l|l|l|}
\hline Name of Plants & Medicinal value & How to use \\
\hline Sulati (Indian name) & $\begin{array}{l}\text { For cough, flu, stomach ache and reduce } \\
\text { pimples }\end{array}$ & Drink the leaf broth \\
\hline Karpuravalli & $\begin{array}{l}\text { For cough and flu, especially for the } \\
\text { baby }\end{array}$ & Drink the leaf broth \\
\hline
\end{tabular}




\begin{tabular}{|l|l|l|}
\hline Curry leaf & $\begin{array}{l}\text { To ensure strong hair and reduce hair } \\
\text { fall }\end{array}$ & Use it in cooking \\
\hline Scallions & For headache & Drink the leaf broth \\
\hline Turmeric leaf & $\begin{array}{l}\text { To reduce pimple appearance and to } \\
\text { reduce body hair }\end{array}$ & $\begin{array}{l}\text { Blend it and apply it on the face or } \\
\text { can also throughout the body }\end{array}$ \\
\hline Lemongrass & To reduce stomach ache & Drink the leaf broth \\
\hline
\end{tabular}

Based on Table 1, students show that they were able to find the information about the names of plants, medicinal value and also how to use it from the themed garden activity. Students in this study also mentioned that before this activity, they just see the plants only as a plant. They didn't know that actually some plants have a healing effect.

In addition, through themed garden project, students not only increase their knowledge on local knowledge but also increase their positive attitudes and practices towards preserving local knowledge. Therefore, the themed garden project is suggested to enhance student's local knowledge on healing.

\section{DISCUSSION}

Based on previous research, the level of awaress about local environmental issues is low among the general public. They also demonstrate poor understanding of ecosystems and low proenvironmental care (Evans et. al., 2007). Louv (2006) also support this finding and blamed the technology for the loss of development on environmental and biological awareness. Prior to the advent of current technology, students may be developed their understanding of the environment and ecology through books and personal observations. Therefore, students were encouraged to familiarise themselves with knowledge about the natural world and its surrounding to develop their environmental awareness.

Little research is available concerning student's ideas concerning plants and their understandings of the plant concept (Boulter, Tunnicliffe, \& Reiss, 2003; Tunnicliffe, Gatt, Agius, \& Pizzuto, 2008). They oftem hold misconceptions and cannot differentiate between plants, trees and shrubs. Plant blindness, yet another term to describe the phenomenon of ignoring plants as they are not there. We pay little attention to plants (Wandersee \& Schussler, 2001). In this study, students also possess very limited knowledge about plants before they participate in this project. They also cannot identify the local name or the species of the plant.

Children are wired into their worlds, surrounded by technologies that make it unnecessary to venture out and play in nature. Some researcher suggests that students know more about rainforest plants and animals than they do the biology in their own back yards. This is because our students are learning organisms only from their textbooks and the Internet, rather than their local environments. Therefore, they have become disconnected from the living things that found in their communities (Bebbington, 2005). This in turn will make students unaware about local knowledge in their communities and the knowledge at the end is buried with the dead practitioners.

Traditionally, this treasure of knowledge has been passed verbally from generation to generation without any written document (Perumal Samy and Ignacimuthu, 2000). Students in this study also mentioned that, they gained knowledge about plants and the related medicinal value from their grandmother. This medicinal value is used and passed down in their family. However, the knowledge of herbal medicine is continually lost over the centuries (Sahri et al., 2012). Similar to the findings in this study, only a few plants can be identified by students related to its name, medicinal values and proper use of it. 


\section{CONCLUSION}

This study provides only the student's local knowledge about plants and their medicinal values in Malaysia. Moreover, this study will promote a practical use of the plants and suggested to undergo pharmacological validation. Further detailed exploration and collection of ethnobotanical information, chemical studies and screening for medicinal properties will provide cost effective and reliable source of medicine for the welfare of humanity.

\section{REFERENCES}

Bebbington, A. (2005). The ability of A-level students to name plants. Journal of Biology Education, 32(2), 62-67.

Boulter, C., Tunnicliffe, S., \& Reiss, M. (2003). Probing children's understandings of the natural world. Paper presented at the Proceedings of the European research in the didactics of biology conference, Toulouse, France.

Bowers, C. A. (2003). Mindful conservativism: Rethinking the ideological and educational basis of an ecologically sustainable future: New York: Rowman \& Littlefield.

CBD. (2010). United Nations Decade on Biodiversity 2011-2020 Retrieved 26/8/2012, 2012, from http://www.cbd.int/2011-2020/

Louv, R. (2006). Last child in the woods: saving our children from nature-deficit disorder. Algonquin Books, Chapel Hill.

Rasadah, M. A. and Li, A. R. (2009). Nutraceutical and cosmetic products developed from Malaysian biodiversity resources, in Yong, H. S. (Ed.) Proceedings of the Conference on Biodiversity and National Development: Achievements, Opportunities and Challenges, Kuala Lumpur, 28 - 30 May 2008, 96 - 102. Kuala Lumpur: Akademi Sains Negara.

Revathi, P. and Parimelazhagan (2010). Traditional knowledge on medicinal plants used by the Irula tribe of Hasanur Hills, Erode District, Tamil Nadu, India. Ethnobotanical Leaflets, 14, 136 - 160

Sahri, Z., Nordin, S., \& Harun, H. (2012, 4 - 6 July 2012). Malaysia Indigenous Herbs Knowledge Representation. Paper presented at the Knowledge Management International Conference (KMICe) 2012, Johor Bahru, Malaysia.

Supiah Mustaffa, Ros'aleza Zarina Ishak, Lee, C. K., Lim, S. N, Sintoh, M. and Nor Ezam Selan (2012). Herbal Medicine Knowledge Base System, Paper presented in, the Agricultural Ontology Service (AOS) Workshop 2012, Kuching

Tikka, P. M., Kuitunen, T. M., \& Tynys, M. S. (2000). Effect of educational background on students' attitudes, activity levels and knowledge concerning environment. The Journal of Environmental Education, 31, 12-19.

Tunnicliffe, S., Gatt, S., Agius, C., \& Pizzuto, S. (2008). Animals in the lives of young Maltese children. Eurasia Journal Mathematics Science \& Technology, 4(3), 215-221.

Wandersee, J., \& Schussler, E. (2001). Toward a theory of plant blindness. Plant Sci Bull, 17(1), 2-9. 
Warren, D. M. (1992). Indigenous knowledge, biodiversity conservation and development. Keynote address at the International Conference on Conservation of Biodiversity in Africa. Local Initiatives and Institutional Roles, 30 August - 3 September 1992, Nairobi, Kenya.

\section{Acknowledgement}

The authors wish to thank funding by the Exploratory Research Grant Scheme, Ministry of Education, Malaysia and Long Term Research Grant Scheme, Ministry of Education, Malaysia for carrying out this research. 